\title{
Breaking the Law's Grip On Equality: A New Paradigm For Section 15
}

Christopher D. Bredt

Adam M. Dodek

Follow this and additional works at: http://digitalcommons.osgoode.yorku.ca/sclr

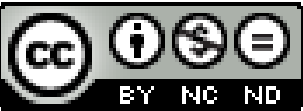

This work is licensed under a Creative Commons Attribution-Noncommercial-No Derivative Works 4.0 License.

\section{Citation Information}

Bredt, Christopher D. and Dodek, Adam M.. "Breaking the Law's Grip On Equality: A New Paradigm For Section 15." The Supreme Court Law Review: Osgoode's Annual Constitutional Cases Conference 20. (2003).

http://digitalcommons.osgoode.yorku.ca/sclr/vol20/iss1/2 


\title{
BREAKING THE $L A W$ 'S GRIP ON EQUALITY: A NEW PARADIGM FOR SECTION 15
}

\author{
Christopher D. Bredt \\ Adam M. Dodek ${ }^{*}$
}

\section{INTRODUCTION}

Equality is an elusive and sometimes divisive concept. The Supreme Court of Canada has struggled with the interpretation of equality, tacking back and forth between periods of unanimity and division in its interpretation of section 15. The late 1980s was a period of unanimity in the Court's initial attempts to define the right to equality under section 15, most notably with Law Society of British Columbia v. Andrews. ${ }^{1}$ However, within a number of years that unanimity broke down as the Court fractured into at least three different approaches to the interpretation of section 15, set out most notably in the 1995 Equality Trilogy. ${ }^{2}$ By 1999 , the Court had returned to unanimity in the Law decision, ${ }^{3}$ setting out a complicated multi-factor contextual analysis conceptually anchored in the idea of human dignity. However, the unanimity of Law proved to be short-lived. By 2002, Law was beginning to rupture at the seams, so that in 2003 we are back to where we were less than eight years ago:

\footnotetext{
* Borden Ladner Gervais LLP Toronto. Christopher Bredt is the National Chair of Borden Ladner Gervais LLP's Constitutional Law Practice Group of which Adam Dodek is a member. The authors would like to express their gratitude to Monique Higham for superb research assistance on this paper and to Jamie Cameron, Elissa Goodman, Brock Martland, Dwight Newman, Josh Paterson and John Pottow for reading earlier drafts of this article and providing helpful comments.

1 [1989] 1 S.C.R. 143 [hereinafter "Andrews"].

2 Miron v. Trudel, [1995] 2 S.C.R. 418 [hereinafter "Miron"]; Thibaudeau v. Canada, [1985] 2 S.C.R. 627 [hereinafter "Thibaudeau"]; and Egan v. Canada, [1995] 2 S.C.R. 513 [hereinafter "Egan"] (collectively the "Equality Trilogy"). after "Law"].

Law v. Canada (Minister of Employment and Immigration), [1999] 1 S.C.R. 497 [herein-
} 
section 15 jurisprudence is entangled in an overly-complicated analysis which produces a high degree of uncertainty. It is not without cause that the Chief Justice of Canada has termed equality "the most difficult right." 4

In this paper, we argue for a revised approach to the interpretation of section 15. We argue that section 15 has become overly "contextualized" which has two effects, both negative. First, the emphasis on context in section 15 has made interpreting equality more elusive than ever, losing the sort of certainty and predictability that is an important element of the rule of law under our Constitution. Second, Law's penchant for context has essentially eviscerated any role for section 1 , which is the proper place where the balancing of interests should take place.

This paper has five parts in addition to this introduction. In Part II, we trace the evolution of the Supreme Court's equality jurisprudence up until Law. In Part III, we analyze and critique the Law decision and its aftermath. ${ }^{5}$ In Part IV, we identify four key principles relevant to the analysis of equality. We then apply these principles in Part V where we propose a simplified, less contextual approach to section 15 which is more akin to the test the Supreme Court originally articulated in Andrews. More particularly, we argue that in analyzing a claim brought under section 15, the Court should apply the following framework: first, the inquiry under section 15 should be confined to two questions: (i) does the law have either the purpose or effect of disadvantaging the claimant; and (ii) is the disadvantage drawn on the basis of one or more enumerated or analogous grounds; and second, if a prima facie violation of section 15(1) is found, the inquiry should move to section 1 where the government bears the burden of justifying the reasonableness of the restriction on equality. In articulating this test, we argue that all considerations of reasonableness are properly considered under section 1 and not under section

4 The Rt. Hon. Beverley McLachlin, P.C., "Equality: The Most Difficult Right” (2001) 14 Sup. Ct. L. Rev. (2d), 17.

5 See Christopher D. Bredt \& Ira Nishisato, "The Supreme Court's New Equality: A Critique" (2000) 8 Canada Watch 16; Christopher D. Bredt \& Adam M. Dodek, "The Increasing Irrelevance of Section 1 of the Charter" (2001) 14 Sup. Ct. L. Rev. (2d), 175, at 181-82. Numerous others have criticized Law: see e.g. Peter W. Hogg, Constitutional Law of Canada, loose-leaf ed. (Toronto: Carswell, 1997), vol. 2, at para. 52.7(b); Beverly Baines, "Law v. Canada: Formatting Equality" (2000) 11 Const. F. 65; Sheilagh Martin, "Balancing Individual Rights to Equality and Social Goals" (2001) 80 Can. Bar Rev. 299, at 319-32; June Ross, "The Supreme Court's New Equality Test: A Critique" (September-October 2000) 8 Can. Watch 16; Jamie Cameron, "A Work in Progress: The Supreme Court and the Charter's Equation of Rights and Limits" in Debra M. McAllister \& Adam M. Dodek, eds., The Charter at Twenty: Law and Practice 2002 (Toronto: OBA, 2002) 31; Lori Sterling, "The Impact of Lovelace v. Ontario on Section 15 of the Charter" (2001) 14 Sup. Ct. L. Rev. (2d) 53, at 59-60. 
15(1). Finally, in Part VI we offer some concluding comments on the challenges of section 15 .

\section{The EARly DeVelopment of SECtion 15 JuRISPRUdence}

The Supreme Court's equality jurisprudence has constantly been a work in progress. To date there have been four identifiable periods in section 15 adjudication: (1) the early period, defined by Andrews and subsequent cases; (2) the fragmentation of equality, defined by the Equality Trilogy; (3) the ascension of unanimity and the Law decision; and (4) the post-Law breakdown of unanimity. This section will analyze the first two periods in the development of the Supreme Court's section 15 jurisprudence.

\section{Equality's Early Years: 1982-1995}

Section 15 provides:

(1) Every individual is equal before and under the law and has the right to the equal protection and equal benefit of the law without discrimination and, in particular, without discrimination based on race, national or ethnic origin, colour, religion, sex, age or mental or physical disability.

(2) Subsection (1) does not preclude any law, program or activity that has as its object the amelioration of conditions of disadvantaged individuals or groups including those that are disadvantaged because of race, national or ethnic origin, colour, religion, sex, age or mental or physical disability.

The first period in the development of equality jurisprudence under the Charter is also the longest. While the Charter came into force on April 17, 1982, section 15's enactment was delayed for three years to give provincial and federal governments time to review their statute books and bring legislation into compliance with the new equality guarantee. ${ }^{6}$ The fundamental difficulty in this exercise was that section 15 had never been judicially considered and it was very difficult for government legal advisors to predict how it would be interpreted. $^{7}$ Thus, the first Supreme Court decision on section 15 was not released until February 1989, over half-way through this initial period.

6 Canadian Charter of Rights and Freedoms, Part I of the Constitution Act, 1982, being Schedule B to the Canada Act 1982 (U.K.), 1982, c. 11 [hereinafter the "Charter"].

7 See Peter W. Hogg, Constitutional Law of Canada, 2nd ed. (Toronto: Carswell, 1985), at 797 [hereinafter Hogg, Constitutional Law of Canada, 2nd ed.]. Professor Hogg identified the central problem with this mandate; it was difficult to provide any sort of confident opinion as to whether any given law would infringe $\mathrm{s}$. 15 before that section had been judicially considered. $I d$. It would have been interesting and perhaps more helpful if the federal government had directed a 
In Law Society of British Columbia v. Andrews, ${ }^{8}$ McIntyre J. set out the Court's initial approach to section $15 .{ }^{9}$ After reviewing various attempts to define discrimination, McIntyre J. articulated discrimination under section 15 in the following terms:

I would say then that discrimination may be described as a distinction, whether intentional or not but based on grounds relating to personal characteristics of the individual or group, which has the effect of imposing burdens, obligations, or disadvantages on such individual or group not imposed upon others, or which withholds or limits access to opportunities, benefits or advantages available to other members of society. Distinctions based on personal characteristics attributed to an individual solely on the basis of association with a group will rarely escape the charge of discrimination, while those based on an individual's merits and capacities will rarely be so classed. ${ }^{10}$

Justice McIntyre reviewed three possible approaches to section 15(1). The first, proffered by Professor Peter Hogg in the 1985 edition of Constitutional Law of Canada, ${ }^{11}$ would treat every distinction drawn by law as discrimination under section 15(1) which must be justified under section 1 . The second approach was one that McLachlin J.A. (as she then was) had put forward in the B.C. Court of Appeal in Andrews and involved a consideration of the reasonableness and fairness of the impugned legislation under section $15(1){ }^{12}$ Justice McIntyre preferred a third approach, the "enumerated or analogous grounds" approach under which discrimination for the purpose of section 15(1) is generally expressed by the enumerated grounds: "Section 15(1) is designed to prevent discrimination based on these and analogous grounds."13

Having defined discrimination in this manner, McIntyre J. explained that "[a] complainant under section 15(1) must show not only that he or she is not receiving equal treatment before and under the law or that the law has a differential impact on him or her in the protection or benefit accorded by law but, in addition, must show that the legislative impact of the law is

reference to the Supreme Court on the application of s. 15 to a particular piece of legislation during the three-year waiting period.

8 Andrews, supra, note 1.

9 Andrews was heard on October 5 and 6, 1989 by Dickson C.J.C., McIntyre, Lamer, Wilson, Le Dain, La Forest and L'Heureux-Dubé JJ. Justice Le Dain took no part in the judgment which was rendered 16 months later on February 2, 1989. Id.

${ }^{10} I d$., at 174-75.

11 Hogg, Constitutional Law of Canada, 2nd ed., supra, note 7, at 797-801.

12 Andrews, supra, note 1, at 179.

13 Id., at 180. Justice La Forest, concurring, left open the possibility that there might be room under s. 15 for judicial intervention "beyond the traditionally established and analogous policies against discrimination discussed by my colleague ....” Id., at 194. 
discriminatory." Furthermore, under Andrews, any consideration of reasonableness or of factors which could justify the discrimination takes place at the section 1 stage. ${ }^{14}$ It is the fleshing out of the "discrimination" component that would later divide and ensnare the Court.

The Andrews enumerated and analogous grounds approach was applied in subsequent cases such as Turpin ${ }^{15}$ and McKinney. ${ }^{16}$ In each of these cases, the Court applied Andrews and its inquiry focused on the question of whether the impugned government action imposed a burden or denied a benefit on the basis of an enumerated or analogous ground. The analysis in this respect was straightforward and issues of justification, explanation or reasonableness of the impugned classification were left, if at all, for section 1. For example, in McKinney, La Forest J., writing for the majority, found that the University of Guelph's mandatory retirement policy was discriminatory within the meaning of section $15(1)$ of the Charter since the distinction was based on the enumerated personal characteristic of age. His analysis was succinct and direct, taking little more than a paragraph. He found that there was no doubt that the mandatory retirement policies imposed a burden on the employees at issue. Next, he determined that mandatory retirement takes away the benefit of working on the basis of the personal characteristic of age attributed to an individual solely because of their association with a group (i.e. workers over $65) .{ }^{17}$

\section{The Fragmentation of Equality: 1995-1999}

Even during section 15's early years, fissures had started to develop in the Court's interpretative approach to equality. Various members of the Court added their own gloss to McIntyre J.'s directive in Andrews that a distinction with respect to an enumerated or analogous group had to be "discriminatory." For example, in McKinney, Wilson J. writing in dissent, opined:

It follows, in my opinion, that the mere fact that the distinction drawn in this case has been drawn on the basis of age does not automatically lead to some kind of irrebuttable presumption of prejudice. Rather it compels one to ask the question: is there prejudice? Is the mandatory retirement policy a reflection of the stereotype of

14 Id., at 182.

15 R. v. Turpin, [1989] 1 S.C.R. 1296 (finding no discrimination under s. 15(1) where provisions of the Criminal Code treated persons charged with an offence in Alberta differently than those charged with the same offence in Ontario; persons resident outside of Alberta charged with an offence could not be considered a "discrete and insular" minority within the contemplation of s. 15(1) of the Charter).

16 McKinney v. University of Guelph, [1990] 3 S.C.R. 229 [hereinafter "McKinney"].

$17 I d$., at 269. 
old age? Is there an element of human dignity at issue? Are academics being required to retire at age 65 on the unarticulated premise that with age comes increasing incompetence and decreasing intellectual capacity? I think the answer to these questions is clearly yes and that s. 15 is accordingly infringed. ${ }^{18}$

These fissures erupted into chasms in the 1995 Equality Trilogy. In these three cases released simultaneously on May 25, 1995 - Miron v. Trudel, ${ }^{19}$ Thibaudeau v. Canada, ${ }^{20}$ and Egan v. Canada $^{21}$ — three distinct approaches to section 15 emerged from the decisions of the Supreme Court. The first test, set out by McLachlin J. (as she then was) in Miron v. Trudel, focused on the application of stereotypes:

The analysis under s. 15(1) involves two steps. First the claimant must show a denial of "equal protection" or "equal benefit of the law, as compared to some other person. Second, the claimant must show that the denial constitutes discrimination. At this second stage, in order for discrimination to be made out, the claimant must show that the denial rests on one of the grounds enumerated in s. 15(1) or an analogous ground and that the unequal treatment is based on the stereotypical application of presumed group or personal characteristics. ${ }^{22}$

In Egan, Cory J., writing for himself and Iacobucci J. (with Sopinka J. expressing his agreement with their analysis), set out the test for a violation of section $15(1)$ in slightly different terms. Their inquiry focused not on "stereotypical application of presumed group or personal characteristics" but rather simply on distinctions that flow from "personal characteristics." 23 Subsequently, Iacobucci J. referred to McLachlin J.'s “stereotypical application" test and Cory J.'s "personal characteristics" test as "essentially alike," which was reflected by Cory, Sopinka, and Iacobucci JJ. concurring with McLachlin J. in Miron. ${ }^{24}$

The second section 15(1) test was set out by Gonthier J. in Miron. It followed McLachlin J.'s approach in that it also required that a distinction be found and that this distinction constitute discrimination. However, in determining what distinctions constitute discrimination, Gonthier J. added a relevancy inquiry. In order for a violation of section $15(1)$ to be established under Gonthier J.'s test, the grounds of the distinction must be irrelevant to the purpose of the legislation. In other words, a denial of equality based on an

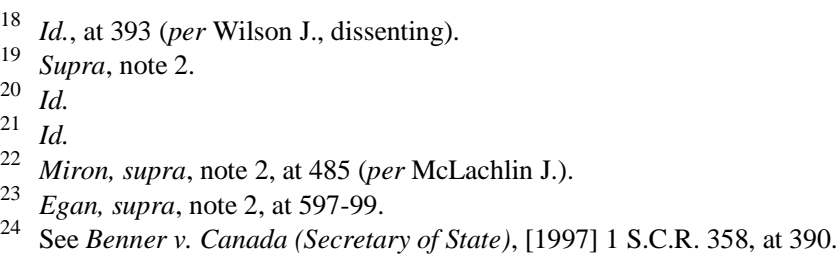


enumerated or analogous ground would not in every case constitute discrimination. Gonthier J. explained his reasoning in the following terms:

To the extent, then, that a law in any given case mirrors or reflects a distinction drawn on such a basis that is relevant to its functional values which are not themselves discriminatory, the distinction drawn by the law will not be discriminatory. ${ }^{25}$

Finally, L'Heureux-Dubé J. set out a third approach in Miron. According to this test, a distinction must first be proven to deny equality rights on the basis of membership in an identifiable group, then that distinction must be shown to be discriminatory. Justice L'Heureux-Dubé rejected the restriction of section 15 to enumerated and analogous grounds. Rather, her test weighed discrimination on a case by case basis by considering (1) the nature of the group affected by the distinction; and (2) the nature of the interest affected by the distinction. Included as discriminatory were those distinctions

... capable of either promoting or perpetuating the view that the individual adversely affected by this distinction is less capable, or less worthy of recognition or value as a human being or as a member of Canadian society, equally deserving of concern, respect, and consideration. ${ }^{26}$

While failing to command the support of any of her colleagues at the time, L'Heureux-Dubé J.'s focus on context and dignity would prove highly influential in the Supreme Court's re-articulation of the equality test in Law v. Canada.

The Supreme Court's fragmentation on the interpretation of section 15 confounded courts and lawyers who were forced to analyze equality claims under three different rubrics and attempt to synthesize the approaches in order to reach some conclusion as to what the governing law from the Supreme Court of Canada was. What emerged during the period between Andrews and Law was "an inchoate mass of principles, tests, and methodologies." 27

\section{LAW'S PROMISE AND FAILURE}

\section{The Rule of Law: 1999-2001}

Within a few years of the Equality Trilogy, it became apparent that the continuation of a regime of fragmented approaches to section 15 was seriously damaging any attempt to develop consistent or coherent jurisprudence in this

\footnotetext{
25 Miron, supra, note 2, at 436 (per Gonthier J.).

26 Miron, supra, note 2, at 465-77 (per L'Heureux-Dubé J.).

27 Cameron, supra, note 5, at 35.
} 
area. Lower court decisions became a guessing game as to how the three different approaches would line up in any particular case. By 1998, when Law v. Canada $a^{28}$ was heard at the Supreme Court, even that Court had apparently come to the conclusion that the fragmentation of section 15 could not continue. In what must have been a Herculean effort of judicial brokering, Justice Iacobucci forged a new unanimous approach to section 15 . Not surprisingly, the "Law approach" combined features from all three separate strands of equality interpretation.

The Supreme Court explained that in articulating a revised approach to the interpretation of section 15(1), it was inappropriate to confine the analysis to a "fixed and limited formula." Instead, "[a] purposive and contextual approach to discrimination is to be preferred, in order to permit the realization of the strong remedial purpose of the equality guarantee, and to avoid the pitfalls of a formalistic or mechanical approach." ${ }^{29}$ The Court then unified its previous jurisprudence, noting that its previous approaches to section 15(1) had focused on three central issues:

(A) whether a law imposes differential treatment between the claimant and others, in purpose or effect;

(B) whether one or more enumerated or analogous grounds of discrimination are the basis for the differential treatment; and

(C) whether the law in question has a purpose or effect that is discriminatory within the meaning of the equality guarantee. ${ }^{30}$

Justice Iacobucci then set out the template for courts to follow in adjudicating discrimination claims under section 15(1). He instructed courts to make the following three broad inquiries:

(A) Does the impugned law (a) draw a formal distinction between the claimant and others on the basis of one or more personal characteristics, or (b) fail to take into account the claimant's already disadvantaged position within Canadian society resulting in substantively differential treatment between the claimant and others on the basis of one or more personal characteristics?

(B) Is the claimant subject to differential treatment based on one or more enumerated and analogous grounds?

and

\footnotetext{
${ }^{28}$ Supra, note 3.

29 Id., at para. 88 .
}

${ }^{30} \mathrm{Id}$. 
(C) Does the differential treatment discriminate, by imposing a burden upon or withholding a benefit from the claimant in a manner which reflects the stereotypical application of presumed group or personal characteristics, or which otherwise has the effect of perpetuating or promoting the view that the individual is less capable or worthy of recognition or value as a human being or as a member of Canadian society, equally deserving of concern, respect, and consideration? ${ }^{31}$

Justice Iacobucci identified the purpose of section 15(1) as preventing the violation of essential human dignity and freedom "through the imposition of disadvantage, stereotyping, or political or social prejudice, and to promote a society in which all persons enjoy equal recognition at law as human beings or as members of Canadian society, equally capable and deserving of respect and consideration." ${ }^{32}$

In the critical next step, Iacobucci J. stated that the existence of a conflict between the purpose or effect of an impugned law and the purpose of section 15(1) was "essential" to a finding of discrimination under that section. Moreover, determining whether such a conflict exists will henceforth require a full contextual analysis surrounding both the claimant and the claim. Law's contextual approach also involves a comparative analysis where the claimant is measured against the appropriate comparator group. ${ }^{33}$ The list of contextual factors are open and include such items as (1) pre-existing disadvantage; ${ }^{34}$ (2) correspondence between the basis for the claim and the actual situation of the claimant $;^{35}$ (3) the ameliorative purpose or effects of the impugned law upon a

31 Id.

32 Id.

33 "The equality guarantee is a comparative concept, which ultimately requires a court to establish one or more relevant comparators. The claimant generally chooses the person, group, or groups with whom he or she wishes to be compared for the purpose of the discrimination inquiry. However, where the claimant's characterization of the comparison is insufficient, a court may, within the scope of the ground or grounds pleaded, refine the comparison presented by the claimant where warranted. Locating the relevant comparison group requires an examination of the subjectmatter of the legislation and its effects, as well as a full appreciation of context." Id.

34 "Pre-existing disadvantage, stereotyping, prejudice, or vulnerability experienced by the individual or group at issue. The effects of a law as they relate to the important purpose of s. 15(1) in protecting individuals or groups who are vulnerable, disadvantaged, or members of 'discrete and insular minorities' should always be a central consideration. Although the claimant's association with a historically more advantaged or disadvantaged group or groups is not per se determinative of an infringement, the existence of these pre-existing factors will favour a finding that s. 15(1) has been infringed." Id.

35 "The correspondence, or lack thereof, between the ground or grounds on which the claim is based and the actual need, capacity, or circumstances of the claimant or others. Although the mere fact that the impugned legislation takes into account the claimant's traits or circumstances will 
more disadvantaged group; ${ }^{36}$ and (4) the nature and scope of the interest affected by the impugned law. ${ }^{37}$

Ultimately, in Law, the Court found that the impugned provision of the Canadian Pension Plan which reduces survivors' pension benefits for surviving spouses between 35 and 45 years of age and excludes them altogether for surviving spouses under 35 years old, did not constitute discrimination within the meaning of section 15(1) because neither the purpose nor the effect of the impugned provision violated the claimant's human dignity.

The Supreme Court applied the Law test with general agreement in the subsequent cases of Corbière v. Canada (Minister of Indian and Northern Affairs), ${ }^{38}$ M. v. H., ${ }^{39}$ and Granovsky v. Canada (Minister of Employment and Immigration).$^{40}$ Importantly, in Lovelace v. Ontario ${ }^{41}$ the Court eschewed a separate step of analysis for affirmative action under section 15(2). Instead, the Court rolled section 15(2) into the contextual mix under section 15(1). By 2002, however, the Law consensus began to show strains.

\section{The Breakdown of the Rule of Law}

In 2002, the Supreme Court's united application of the Law test broke down, revealing problems with Law's methodology itself. First, in Lavoie v. Canada, ${ }^{42}$ four different opinions emerged in a challenge to the constitutionality of a provision of the Public Service Employment Act, which affords preferential treatment to Canadian citizens in the federal public service. ${ }^{43}$ Second, in

not necessarily be sufficient to defeat a s. 15(1) claim, it will generally be more difficult to establish discrimination to the extent that the law takes into account the claimant's actual situation in a manner that respects his or her value as a human being or member of Canadian society, and less difficult to do so where the law fails to take into account the claimant's actual situation." Id.

36 "The ameliorative purpose or effects of the impugned law upon a more disadvantaged person or group in society. An ameliorative purpose or effect which accords with the purpose of $s$. 15 (1) of the Charter will likely not violate the human dignity of more advantaged individuals where the exclusion of these more advantaged individuals largely corresponds to the greater need or the different circumstances experienced by the disadvantaged group being targeted by the legislation. This factor is more relevant where the s. 15(1) claim is brought by a more advantaged member of society." Id.

37 "The more severe and localized the consequences of the legislation for the affected group, the more likely that the differential treatment responsible for these consequences is discriminatory within the meaning of s. 15(1)." Id.

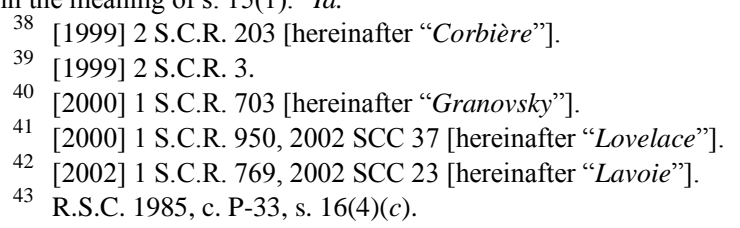


Gosselin v. Quebec (Attorney General), ${ }^{44}$ the Court split 5-4 on whether Quebec welfare legislation, which provided reduced benefits for individuals under the age of 30 who were not in job training programs, violated section 15(1) of the Charter.

In Lavoie, seven of the nine justices found that the impugned provision violated section 15, but for two different reasons. Moreover, four of those seven justices upheld the law under section 1 which meant that when coupled with the two justices who did not find a section 15(1) violation, the impugned provision was upheld by the Court 6-3. On one approach to section 15(1), Bastarache J. (Gonthier, Iacobucci and Major JJ., concurring) held that the law imposed differential treatment on the analogous ground of citizenship. He termed the impugned preferences "substantive discrimination" because differentiating between citizens and non-citizens was not based on individual capacity or merit, but rather on a stereotypical differentiation that burdened an already disadvantaged group. On another approach, McLachlin C.J.C. and L'HeureuxDubé J. (with Binnie J. concurring), also found that the law violated section 15, but emphasized that it violated human dignity by forcing individuals who sought employment from the public service to become citizens: "[t]he very act of forcing some people to make such a choice violates human dignity, and is therefore inherently discriminatory." 45 Justice Arbour, writing for herself, found no violation of section 15(1). She was sharply critical of Bastarache J.'s focus on the subjective element to the human dignity inquiry, raising the alarm that it threatened irrevocable damage to the Law methodology. ${ }^{46}$ Examining the various contextual factors, Arbour J. concluded that the impugned law did not violate essential human dignity and thus was not discriminatory within the meaning of section 15(1). Justice LeBel concurred in Arbour J.'s assessment of this issue. $^{47}$

In Gosselin, decided in December 2002, the breakdown of the rule of Law continued. The case involved a challenge to a Quebec regulation that provided for reduced welfare benefits for individuals under 30 who were not participating in training or work experience programs. ${ }^{48}$ In a 5-4 decision, the Supreme Court decided that the impugned regulation did not violate section 15(1). ${ }^{49}$ Chief Justice McLachlin, writing for herself and Gonthier, Iacobucci,

442002 SCC 84 [hereinafter "Gosselin"].

45 Lavoie, supra, note 42, at para. 5.

46 Id., at paras. 80-81 (per Arbour J.).

47 Id., at para. 124. He wrote separately to distance himself from Arbour J.'s comments regarding the application of s. 1. Id., at para. 125.

48 See Regulation Respecting Social Aid, R.R.Q. 1981, c. A-16, r. 1, s. 29(a).

49 A challenge to the impugned regulations was brought under both s. 7 and s. 15. The Court held 7-2 that the regulations did not violate s. 7, with L'Heureux-Dubé and Arbour JJ., dissenting. 
Major, and Binnie JJ., held that the claimant had failed to discharge her burden of proof under the third branch of the Law test. According to the Court, the claimant had failed to demonstrate that the government treated her as less worthy than older welfare recipients simply because it conditioned increased payments on her participation in programs that were specifically designed to integrate her into the workforce and to promote her long-term self-sufficiency. The four dissenters took three different approaches to their collective conclusion that the impugned regulation violated the claimant's human dignity and thus infringed her right to equality under section $15(1) .{ }^{50}$ Gosselin thus provides four separate analyses under the Law test and four different conceptions of the human dignity at issue in the case.

\section{A Critique of Law}

The Law methodology suffers from numerous problems, both practical and principled. ${ }^{51} \mathrm{We}$ focus on three: (i) the complexity and indeterminacy of the Law methodology; (ii) Law's usurpation of section 1's role; and (iii) Law's creation of a "hierarchy of suffering." 52

On the first point, a rather indicting critique was recently set out by Professor Jamie Cameron:

Under the burden of layered and overlapping criteria, Charter analysis has become less accessible, to the point at times of impenetrable. For instance, the question of breach under section 15 is answered by a multi-step test, which incorporates subdivisions and further guidelines. That side of the equation is then followed by the several parts of the Oakes test, which is applied to determine whether limits are justifiable. Yet with prolix, cumulative doctrines the probability that the boundaries between breach and justification will blur can only crease. In addition, to escape the needless convolution of such doctrines, the Court has inserted subjective criteria into the mix. Co-existing alongside abstract doctrines in the jurisprudence are perceptive concepts like context, vulnerability, and human dignity. More often than not, those considerations, and not the even-handed application of a structured methodology, determine the outcome. To summarize, the Court claims adherence to a structured methodology and then employs result-oriented criteria to decide

50 The dissenters were united in their conclusion that the infringement of s. 15(1) was not saved under s. 1 of the Charter.

51 Law is not without its defenders: see Donna Greschner, "Does Law Advance the Cause of Equality" (2001) 27 Queen's L.J. 299 (concluding that while Law contains certain problems, the framework it establishes is preferable to alternatives); Errol P. Mendes, "Taking Equality Into the 21 st Century: Establishing the Concept of Equal Human Dignity" (2000-01) 12 N.J.C.L. 3 (lauding "the dominant artistic vision" of "equal human dignity").

52 Other criticisms of Law are contained in the articles referenced in note 5, supra. 
cases. Charter adjudication does not take place under a methodology but rather, under the cover of methodology. 53

Simply put, the Law methodology is overly complex and fails to articulate a workable standard that can be applied with any degree of objectivity: "its criteria are long-winded, intertwined, abstract, and yet, as the Court cautioned, not exhaustive at that. ... Law has confirmed that adding layers upon layers of doctrinal criteria does not lend precision to the decision making process." Law's open-ended multi-factor test fails to provide trial judges with sufficient tools to balance various considerations, and fails to instruct judges how all the various factors are to be added up in order to reach a reasoned rather than adhoc or results-oriented conclusion. ${ }^{55}$ The indeterminacy of Law undermines the rule of law. ${ }^{56}$

For all its complexity, the Law methodology seems to boil down to a single inquiry: does the impugned provision violate human dignity? Human dignity is a hopelessly abstract concept. While objectivity could likely be reached on a few core aspects of human dignity such as the right to be free from torture, venturing beyond this small core becomes hazy and subjective very quickly. ${ }^{57}$ The problem with human dignity is that it says nothing more specific about the content of section 15 than it does about any other section of the Charter. Human dignity "underlies the entire Charter and therefore cannot serve to differentiate equality rights from other Charter rights. If anything ... 'dignity belongs more to the realm of individual rights than to group based historical disadvantage." 58

Second, the Law methodology usurps the role of section 1. Under Law, the purpose of the legislation is considered at both the section 15 and the section 1

53 Cameron, supra, note 5, at 32.

54 Id., at 35.

55 Professor Greschner has defended the complexity and subjectivity of Law on the grounds that discrimination is a complex concept: "An effective approach [to s. 15] will be complex because the phenomenon of inequality is complex. It is well to remember the old adage: for every complex problem, there is a simple answer, and it is always wrong." Greschner, supra, note 51, at 317-18. We are mindful of the complexity of the issue. Our response is that these complex issues should be determined, at the s. 1 stage where the government bears the burden of demonstrating whether the impugned provision or program is justifiable.

56 On the meaning and importance of the Rule of Law, see Reference re Resolution to amend the Constitution, [1981] 1 S.C.R. 753, at 805-06 [hereinafter "Patriation Reference"] and Reference re Secession of Quebec, [1998] 2 S.C.R. 217, at para. 70 [hereinafter "Quebec Secession Reference"].

"While it may be easier to determine when human dignity is demeaned, it will be more difficult to articulate why it is not." Martin, supra, note 5, at 329. Even one of Law's few defenders acknowledges that Law's focus on human dignity is misplaced. See Greschner, supra, note 51, at 312-13 ("Dignity becomes an assertion, not an analysis.").

58 Greschner, supra, note 51, at 312 quoting Martin, supra, note 5, at 329. 
stage. As well, the test articulated by the Court for the determination of "discrimination" under section 15(1) contains many of the same elements found in the proportionality part of the section 1 analysis. Finally, the heavy reliance on "context" in section 1 is matched by the Court's insistence on "context" in the application of the section 1 test..$^{59}$ The effect of this overlap is to create a repetitive test which, as applied, tends to strip section 1 of any meaningful role. At least one member of the Court has acknowledged this problem. ${ }^{60}$ What the Court has called "purposive interpretation" in defining the right under section 15 , is in fact an exercise in the determination of the reasonableness of the classification at issue. Under Law, justification takes place under the guise of purposive interpretation.

Finally, certain aspects of the Law methodology are highly problematic. For instance, the focus on the comparator group and the history of discrimination and disadvantage creates a "race to the bottom." In the quest to be measured against the appropriate comparator group, a claimant is required to prove that his or her group is more disadvantaged that the comparator group lest they find themselves in the situation of the temporarily disabled claimant in Granovsky, informed by the Court that he is better off, compared with the permanently disabled. This analysis invites the creation of a hierarchy of suffering.

\section{Key PRINCIPLES OF EQUality ANALYSIS}

In developing a framework for the analysis of equality claims under the Charter, there are essentially four elements that must be considered: (a) the classification; (b) the purpose of the legislation; (c) the effect of the legislation; and (d) the reasonableness of the classification in the context of the legislation. These principles are not controversial; they can be found in the Supreme Court's equality jurisprudence from Andrews to Law. The issue is at what stage of the Charter inquiry - breach or justification - each factor should be considered. These elements constitute the background principles for consideration of any framework for analysis under section 15 .

\section{Classifications}

Classifications matter. Common sense tells us that we should be more concerned about some classifications than others. Our response would differ to a tax imposed by the government on members of a particular racial group than

59 Bredt \& Nishisato, supra, note 5. See also Bredt \& Dodek, supra, note 5, at 181-82.

60 See Gosselin, supra, note 44, at para. 244 (per Bastarache J.). 
it would to a tax imposed on coffee drinkers. ${ }^{61}$ Classification mattered to the drafters of the Charter who made the choice to enumerate certain classifications in section 15. It certainly mattered to members of groups who were enumerated in section 15 who thought their inclusion under that section indicated some level of constitutional protection. Classification mattered to groups excluded from section 15 who fought vigorously for the inclusion of additional classifications, some successfully (e.g., disability) and some unsuccessfully (e.g., sexual orientation). No test under section 15 can ignore the text of the Charter that gives credence to certain classifications. The use of classifications reflects the belief that a conception of equality grows out of the experience of discrimination against particular vulnerable groups in society and the collective feeling of uneasiness about using certain classifications in legislation. ${ }^{62}$

\section{Purpose of the Legislation}

All legislation creates classifications. An important step in the equality analysis must therefore be an analysis of the purpose of the legislation. This step will seek to determine what the legislation is trying to accomplish and

61 The problem of "adverse effects" or "constructive discrimination" is discussed below in the section on the Effect of the Law.

${ }^{62}$ There is nothing novel about the concern with classifications in the Charter; it has become an international phenomenon, since at least the Universal Declaration of Human Rights (the "Universal Declaration") in 1948. Article 2 of the Universal Declaration of Human Rights provides, in pertinent part: "Everyone is entitled to all the rights and freedoms set forth in this Declaration, without distinction of any kind, such as race, colour, sex, language, religion, political or other opinion, national or social origin, property, birth or other status." Constitutional bills of rights such as the Charter tend to be concerned about classifications and manifest this concern in different ways. Modern bills of rights tend to follow the example of the Universal Declaration and expressly enumerate certain classifications that are constitutionally protected. For example, the South African Bill of Rights (1996) which was strongly influenced by the Charter, provides in its equality section that: "The state may not unfairly discriminate directly or indirectly against anyone on one or more grounds, including race, gender, sex, pregnancy, marital status, ethnic or social origin, colour, sexual orientation, age, disability, religion, conscience, belief, culture, language and birth." Constitution of the Republic of South Africa, Act 108 of 1996, s. 8(3). The New Zealand Bill of Rights, while not a constitutional bill of rights, takes a similar approach. See New Zealand Bill of Rights Act of 1990, s. 19, as amended ("Everyone has the right to freedom from discrimination on the grounds of discrimination in the Human Rights Act 1993.") (The Human Rights Act 1993 enumerates specific prohibited grounds of discrimination). See "Freedom from Discrimination" in Paul Rishworth et al., eds., The New Zealand Bill of Rights (Oxford and New York: Oxford University Press, 2003). An older bill of rights, such as the American which does not expressly enumerate classifications, uses classifications through the development of different levels of scrutiny for "suspect", "semi-suspect" and "non-suspect" classes. As noted by the Chief Justice of Canada, we can learn from the experience of other countries in interpreting our own Constitution. McLachlin, supra, note 4 , at 27 . 
make a judgment about the importance of the legislative objective. Some legislative purposes are pedestrian whereas others may be critical to the wellbeing of the nation. There is a difference, in short, between legislation that authorizes spending for road repair and legislation that declares martial law in time of war. Some transparent discussion of the purpose of the legislation is necessary in all equality analyses.

\section{Effect of the Law}

The effect of the legislation is relevant in two respects. First, it is relevant in the sense of the interests being affected by the legislation in question. There is a difference between the imposition of a height and weight requirement as a job requirement and its imposition at a carnival ride. Leaving aside issues of reasonableness, the effect of the height and weight requirement in the first instance is more severe because employment is a much more important interest than the opportunity to go on a carnival ride. Any equality test must give some consideration to the interests at stake.

The effect of the legislation is relevant in the second respect in terms of its impact on particular classifications. Laws may explicitly invoke "suspect" classifications, but many laws may use one form of classification that has an "adverse impact" on other classifications. For example, imposing a requirement that firefighter candidates must be at least six feet tall and 200 pounds in weight imposes a classification on its face relating to height and weight. However, it may be demonstrated, through empirical data, that these height and weight requirements have an adverse impact on other classifications which are more suspect than height and weight, such as sex or race.

\section{Reasonableness of the Classification}

Determining the reasonableness of the classification in the context of the legislation in issue is the most important and the most difficult part of the equality analysis. It also contains the greatest aspect of subjectivity: reasonable people will disagree on the reasonableness of the use of particular classifications in various contexts. ${ }^{63}$ Given the inescapable subjectivity of this inquiry, it is important that the reasonableness inquiry be as transparent as possible in order to protect the courts' legitimacy. There are a number of

63 We believe that Law's human dignity analysis is an overly complex means of layering this inquiry into reasonableness. Cases such as Lavoie and Gosselin can be reduced to a difference of opinion among members of the Court as to the reasonableness of considering citizenship for public service jobs (Lavoie) and of using age to restrict welfare benefits (Gosselin). 
factors that the courts have often considered, but which are not always expressly identified as relevant factors in the reasonableness inquiry. These include: (i) whether the legislation is over or underinclusive; and (ii) the nature of the classification. These should be identified and addressed by courts directly in an open and frank manner. We discuss these two factors in more detail below.

\section{(a) Over- and Underinclusive Legislation}

The first consideration is whether the impugned legislation is over- or underinclusive. In an influential 1949 law review article which has been (in our view unfairly, ${ }^{64}$ maligned because it was seen as the genesis of the "similarlysituated" test, Tussman and tenBroek explain the relationship between the purpose of the legislation and the classifications used by the law. ${ }^{65}$ There are five possible relationships between the class defined by the legislation's purpose and the class defined by the trait identified in any legislation:

(i) There can be complete overlap between the purpose of the legislation and those affected by it, and vice-versa; in Oakes ${ }^{166}$ terms, the "least restrictive means" has been used to achieve a perfect fit between the objective of the law and the means chosen;

(ii) There can be complete asymmetry between the objective of the legislation and those affected by it, and vice versa; in Oakes' terms, there is no "rational connection" between the objective and the means chosen;

(iii) The legislation is underinclusive because it applies only to a subset of the group that falls within the purpose of the legislation;

(iv) The legislation is overinclusive because it applies to a larger group than necessary to accomplish the purpose of the legislation; and

(v) The legislation is both overinclusive and underinclusive because in classifying the group covered by the legislation it both overshoots and undershoots its purpose.

64 This view is shared by the Court of Appeal for Ontario. See Catholic Children's Aid Society of Metropolitan Toronto v. S. (T.) (1989), 69 O.R. (2d) 189, at 205-206 (C.A.).

65 See Joseph Tussman and Jacobus tenBroek, "The Equal Protection of the Laws" (194849) 37 Cal. L. Rev. 341. We believe that many of the ideas proffered by Tussman and tenBroek continue to maintain strong empirical and normative force despite attempts by courts and commentators to disassociate themselves from the "similarly-situated" enquiry. We believe that their ideas of underinclusiveness and overinclusiveness have always been part of equality analysis in Canada and are a necessary but not sufficient part of any reasonableness inquiry.

${ }^{66}$ R. v. Oakes, [1986] 1 S.C.R. 103 [hereinafter "Oakes"]. 
These concepts are best understood through concrete examples. Consider the situation where the state determines to legislate qualifications for firefighters. It needs firefighters to have a certain minimum strength in order to be able to haul heavy equipment and carry people out of burning buildings. As a result of its experience, the state knows that it needs its firefighters to have the capacity to carry a 200 pound object over 50 metres. It also knows that statistical evidence shows that most people who are six feet tall or over and weigh at least 200 pounds will be able to complete this task. If the state sets a requirement that "All firefighter candidates must be able to carry at least 250 pounds over 50 metres", this law will be underinclusive because while everyone within the group will meet the purpose of the law, there will be others (who can carry between 200 and 249 pounds over 50 metres) who will be excluded but meet the target or purpose of the law. If the requirement is changed to, "All firefighter candidates must be able to carry at least 150 pounds over 50 metres" it becomes overinclusive because it will include everyone who can meet the purpose of the law (200 pounds over 50 metres), but it will also include others who cannot (150-199 pounds over 50 metres). The requirement may be both underinclusive and overinclusive at the same time, consider: "All Firefighter candidates must be at least six feet in height and 200 pounds in weight." This is underinclusive, because it excludes those people who do not meet the requirements but who are actually capable of meeting the law's purpose, i.e., of carrying 200 pounds over 50 metres. It is also overinclusive because it will include some people who meet the height and weight requirement but who are not able to meet the law's purpose of carrying 200 pounds over 50 metres. When the requirement is changed to "All firefighter candidates must be able to carry at least 200 pounds over 50 metres" then it accords perfectly with its purpose.

Generally, we consider underinclusiveness to be more reasonable than overinclusiveness on the grounds that the legislature should be given some latitude in addressing a social problem in a step-by-step approach and not be forced to address the entire problem at first instance, lest it never actually do so. Underinclusiveness is especially tolerated when it comes to government spending and benefits; cases like Granovsky are better explained in terms of tolerance for underinclusiveness in government benefit programs than by any recourse to human dignity. 


\section{(b) Nature of Classification}

In determining reasonableness, the nature of the classification is also an important factor. ${ }^{67}$ We believe that it is implicit in the Supreme Court's decisions in cases such as McKinney, ${ }^{68}$ Law $^{69}$ and Gosselin ${ }^{70}$ that discrimination on the basis of age is more reasonable than discrimination on the basis of other grounds, such as race or religion. However, it is important that this implicit assumption be expressly acknowledged and justified. Distinctions based on age are more reasonable because they impact all members of society, although not at the same point in time. Classifications based on age are only unequal when one looks at them at a specific point in time. However, when examined over the course of a lifetime, all members of society are potentially subject to such classifications, which mitigates potential unfairness to some degree. ${ }^{71}$ In this sense, age is not immutable in the same way that race, colour or national origin are. Classifications based on those latter grounds impose a "legislative tax" on a select portion of the population that will never be shared by its other members. $^{72}$ The "unfairness" of distinctions based on age is more fairly distributed throughout the population than distinctions based on other classifications.

As noted at the outset, all of these factors are already part of the Supreme Court's approach to the interpretation of section 15(1). The next part of the paper considers how they should be distributed between section 15(1) and section 1 .

67 American jurisprudence makes this explicit through different "levels of scrutiny."

68 Supra, note 16

69 Supra, note 3.

70 Supra, note 44.

71 Thus, restrictions that impose minimum ages to vote, drive or purchase alcohol are burdens that all members of society will share in. Similarly, age restrictions imposed on persons aged 65 and beyond are burdens in which all members of society will share.

72 We have taken this idea from Randall Kennedy, Race, Crime and the Law (New York: Vintage Books, 1997), at 158-61. Professor Kennedy explains racial profiling in policing in terms of the imposition of a "racial tax" on certain minority groups. For example, "When a MexicanAmerican motorist is selected for questioning in part on the basis of his perceived ancestry, he is undoubtedly being burdened more heavily at that moment on account of his race than his white Anglo counterpart. He is being made to pay a type of racial tax for the campaign against illegal immigration, that whites, blacks, and Asians escape. Similarly, a young black man selected for questioning by police as he alights from an airplane or drives a car is being made to pay a type of racial tax for the war against drugs that whites and other groups escape. That tax is the cost of being subjected to greater scrutiny than others." Id., at 158-59. 


\section{A RENEWEd APPROACH to SECTION 15}

For the reasons set out in part III, the Law framework is both unworkable in practice and undesirable in principle, and should be abandoned. Instead, we argue in favour of a return to a modified version of the Andrews test. In this approach, the issue of the reasonableness of the classification in the context of the legislation is reserved for section 1 . The inquiry under section 15 thus becomes a much simpler determination of whether the classification in question is based on an enumerated or analogous ground and whether it creates a disadvantage. ${ }^{73}$

\section{The Question of Breach - Section 15(1) Analysis}

\section{(a) The Two-Step Approach}

In the modified Andrews approach that we propose, the inquiry of whether there is a breach under section 15 of the Charter would be restricted to a twopart test: (1) does the legislation have either the purpose or effect of distinguishing between the claimant and others based on an enumerated or analogous ground; and (2) does that distinction disadvantage the claimant? If the answer to both these questions is yes, then the matter proceeds to section 1 for a consideration of whether the prima facie infringement of section 15 is justified as a "reasonable limitation" on equality rights.

This proposed approach restricts the application of section 15 to enumerated and analogous grounds. In section (c) of this part, we explain the basis for this. We note that if it is established that the legislation has the purpose or effect of distinguishing between the plaintiff and others on an enumerated ground or on the basis of an acknowledged analogous ground (such as citizenship or sexual orientation), all that is left for the claimant to establish in order to proceed to section 1 is that the legislation disadvantages members of the enumerated/analogous ground.

\section{(b) Analogous Grounds}

If the claimant seeks to found a claim based on an analogous ground that has not been previously recognized, the claimant will carry the burden of establishing that the court should recognize a particular classification as

73 We have consciously avoided discussion of the role of s. 15(2) in this paper. The special considerations of s. 15(2) necessitate detailed consideration which is beyond the scope of this paper. 
analogous to those that are enumerated under section 15(1). ${ }^{74}$ The Supreme Court's jurisprudence in this area is helpful and should be followed. According to the Court, an analogous ground is one that is based on "a personal characteristic that is immutable or changeable only at unacceptable cost to personal identity." 75 In Andrews, La Forest J., in recognizing citizenship as an analogous ground, stated as follows: "The characteristic of citizenship is one typically not within the control of the individual and, in this sense, is immutable. Citizenship is, at least temporarily, a characteristic of personhood not alterable by conscious action and in some cases not alterable except on the basis of unacceptable costs. ${ }^{.76}$ The Court has also emphasized that historical disadvantage is an important factor to consider in determining an analogous ground. ${ }^{77}$

\section{(c) The Limited Notion of Disadvantage}

The determination of "disadvantage" at the breach step should be a limited and primarily factual inquiry. In Andrews, McIntyre J. rightly concluded that section 15(1) was designed to prevent discrimination based on the enumerated and analogous grounds. ${ }^{78}$ In subsequent cases, various justices seized on McIntyre J.'s use of the term "discrimination" in order to construct additional qualifiers on the section 15 inquiry. While invoking Andrews, these subsequent decisions strayed from the limitations imposed by McIntyre J. on the discrimination inquiry. ${ }^{79}$

We have used the word "disadvantage" because of the loaded nature of the term "discrimination" and the extent to which it has been used after Andrews to embark on what are essentially inquiries into the reasonableness of the classification at issue. However, we agree with what McIntyre J. envisioned at

74 For a good discussion of the characteristics of the enumerated grounds, see Peter W. Hogg, Constitutional Law of Canada, loose-leaf ed. (Toronto: Carswell, 1997), at s. 52.7(c) [hereinafter Hogg, Constitutional Law of Canada, looseleaf-ed.].

${ }_{75}$ Corbière, supra, note 38, at para. 13 (per McLachlin and Bastarache JJ., for the majority).

76 Andrews, supra, note 1, at 195 (per La Forest J.).

77 See Egan, supra, note 2, at 498 (per McLachlin J., Sopinka, Cory and Iacobucci JJ., concurring).

78 Andrews, supra, note 1, at 180.

79 According to Professor Cameron, "Andrews left unresolved whether a classification based on prohibited grounds would establish a breach, or whether section 15 required proof, in addition, that the classification was discriminatory. The possibility that the prohibited grounds might not suffice created new opportunities for section 1's function to invade section 15." Cameron, supra, note 5, at 34. We agree with Professor Cameron that Andrews left this possibility open; however, for the reasons described above, we believe that the discrimination inquiry envisioned by Andrews was a limited one which did not invade the province of s. 1 . 
the breach step in determination of whether there was discrimination/disadvantage for the purposes of section 15(1). As McIntyre J. explained the term, the discrimination inquiry under section $15(1)$ is a limited one. It is restricted to determining whether the impugned distinction "has the effect of imposing burdens, obligations, or disadvantages on such individual group not imposed upon others, or which withholds or limits access to opportunities, benefits or advantages available to other members of society." 80 In short, the discrimination inquiry under section $15(1)$ is restricted to determining a prima facie disadvantage. This should not involve a detailed objective/subjective inquiry into whether a reasonable person considering all the circumstances of the claimant would consider that the distinction was discriminatory in a purposive sense or whether the distinction impairs human dignity. Such inquiries are all thinly-veiled attempts at justification which are properly the subject of section 1 .

\section{(d) Disadvantage in Purpose or Effect}

Legislation that clearly disadvantages the claimant on the basis of an enumerated and analogous ground will make it relatively simple for the claimant to establish a prima facie breach and proceed to section 1: "No women may be firefighters." However, much discrimination is subtler and is the result of the discriminatory impact of a facially-neutral provision on a class: "All firefighters must be at least six feet tall and weigh at least 200 pounds." In the last example, the proposed legislation may have an adverse impact on members of an enumerated group, such as sex or race. In this instance, the claimant will be required to adduce evidence to carry the burden of proof of demonstrating that the impugned legislation has the effect of creating a disadvantage based on an enumerated or analogous ground. This should be primarily a factual inquiry and not involve normative considerations as to the legislation's reasonableness.

\section{The Question of Justification - Section 1 Analysis}

At the section 1 stage, the government bears the burden of justifying that the impugned provision is a "reasonable limitation" in a free and democratic society. It is at this stage that it is proper for the court to make all determinations as to the reasonableness of the legislative classification in the context of the purpose of the legislation. There are three essential components to justification under section 1: (i) an inquiry into the purpose of the legislation;

80 Id., at 174. 
(ii) a review of the classification in question; and (iii) a determination of how closely tailored the classification is to the purpose of the legislation.

\section{(a) Purpose of the Legislation}

In considering the purpose of the legislation, the court should inquire into what it is that the legislation is seeking to accomplish and how important that objective is. It should be acknowledged that not all purposes are "pressing and substantial," yet the government may ultimately be able to demonstrably justify a limit as "reasonable" in a free and democratic society on the strength of other factors. The purpose of a restriction on washrooms to "Men" and "Women" is difficult to articulate as "pressing and substantial." The government should be forced to articulate the importance of its legislative objective or administrative rule and courts should be required to classify the importance of the purpose as "ordinary," "important" or "pressing and substantial."

\section{(b) The Classification in Question}

The Oakes test is not particularly well-suited for this inquiry and should be modified to expressly acknowledge what the Court has implicitly accepted: different classifications will attract varying degrees of deference. It is extremely difficult to imagine the Court giving much deference to classifications based on race whereas the Court has demonstrated a high degree of deference for classifications based on age. ${ }^{81}$ These different standards of scrutiny should be expressly articulated by the Court.

\section{(c) The Question of Fit}

The court should consider how appropriate the classification is in connection to the purpose of the legislation. Consideration should be given to whether the legislation extends a benefit or imposes a burden and whether the legislation is underinclusive or overinclusive. For the reasons given above, underinclusive legislation will often be easier to justify than overinclusive legislation.

\section{Rationales and Response to Critics}

The approach proposed, which requires classifications based on enumerated and analogous grounds to show only a disadvantage and leaves to section 1 the question of the reasonableness of the classification, is supported by (i) the text

81 See discussion in parts II and III, supra, regarding McKinney, Law, and Gosselin. 
and history of the Charter; (ii) the structure of the Charter; and (iii) the importance of greater transparency and clarity to the rule of law.

\section{(a) Respect for the Text}

Our proposed approach gives pride of place to the grounds enumerated in the text of section 15 and those that are "analogous" to them. It is submitted that certainly some weight must be given to the text of section 15 which expressly enumerates certain grounds of discrimination. The focus on enumerated and analogous grounds under section 15(1) accords with the constitutional history and purpose of this section. Section 15 was not enacted in a vacuum. As has been recognized repeatedly, a constitutional right to equality was enshrined in the Charter against the backdrop of the perceived failures of the Canadian Bill of Rights and the history of discrimination in this country against specific groups. In the public hearings before the Special Joint Committee, equalityseeking groups testified about concrete experiences of discrimination that they had experienced or faced in Canadian society for which they sought a remedy in section 15; they did not seek a means that would require them to convince courts that their human dignity was being impaired on a case-by-case basis. ${ }^{82}$ In short, having fought to be specifically included under section 15 , members of equality-seeking groups should not have to establish a prime facie violation of section 15 anew in each equality case. ${ }^{83}$ The reference to discrimination in

82 In an impassioned testimony before the Special Joint Committee on the Constitution, David Lepofsky on behalf of the Canadian National Institute of the Blind, detailed concrete examples of legislative distinctions against the handicapped which disadvantaged them. Similarly, representatives of the Canadian Black community and the Japanese-Canadian community spoke of their experiences with discrimination. Simply put, in interpreting the Charter, one must take account of the history of discrimination in Canada against particular groups: the internment of Japanese Canadians; the persecution of Jehovah's Witnesses in Quebec, the treatment of the Chinese in British Columbia and the imposition of the head tax.

${ }^{83}$ We cannot put the issue better than Mr. Wilson Head who as President of the National Black Coalition of Canada testified as follows before the Special Joint Committee on the Constitution:

$\ldots$ in the final analysis it should be up to the government itself to say why certain rights are abrogated. It should not be up to the people to have to continue to fight for the rights, the government should confer these rights in a very general sense on the one hand, but specific on another, and at the same time say that if the government wishes to restrict these rights in any way, let the government make the case; that the burden of proof be upon the government to make the case that these rights ought to be abrogated.

Canada, Minutes of Proceedings and Evidence of the Special Joint Committee of the Senate and of the House of Commons on the Constitution of Canada, 1st session of the 32d Parliament, 1980-81, 22:11 (December 9, 1980) [hereinafter "Proceedings of the Special Joint Committee on the Constitution"]. 
section 15 should also be understood in light of the development of human rights acts which protected against discrimination on various enumerated grounds. Section 15 was largely modelled after these acts. ${ }^{84}$

Moreover, our argument for a return to a limited Andrews-like approach to breach is supported by the text of section 15(2) which provides that "Subsection (1) does not preclude any law, program or activity that has as its object the amelioration of conditions of disadvantaged individuals or groups including those that are disadvantaged because of race, national or ethnic origin, colour, religion, sex, age or mental or physical disability." The use of the term "disadvantaged" in section 15(2) supports the interpretation of "discrimination" that we propose for section 15(1).

\section{(b) Structure of the Charter}

A limited inquiry under section 15(1) also accords with the constitutional structure of the Charter. Numerous scholars have written about the structure of the Charter and its separation of rights and limits. ${ }^{85}$ Interpretive theories should respect the text's separation between "breach and justification." $" 86$

To date, the Court has not lent sufficient credence to the burden placed on government to justify limitations on rights under section 1 . In part, this is due to the Court painting itself into a corner through the rigidity of the Oakes analysis. Every section 15(1) analysis is undertaken with the sword of Oakes hanging over a court's head which, if minimal impairment is to be taken seriously, is likely to torpedo most limitations on equality. The judicial response has been to use the malleable concepts of "substantive equality," discrimination and human dignity to sidestep Oakes. However, this interpretive choice has profoundly negative consequences for Charter adjudication.

The purpose and the logic of the Charter requires governments to justify limitations on Charter rights. "Any test of discrimination which asks whether the differential treatment is reasonable or unreasonable, permissible or impermissible, is another way of inquiring whether it is justifiable or not." ${ }^{17}$ Importing any justification criteria into section 15 requires the rights claimant to prove that the limit is not justified - in essence to prove a negative. Not only is this logically problematic but it presents the rights claimant with a daunting evidentiary task. In cases of adverse effects discrimination, a rights

84 Andrews, supra, note 1, at 172.

85 See e.g. Lorraine E. Weinrib, "The Supreme Court of Canada and Section 1 of the Charter" (1988) 10 Sup. Ct. L. Rev., 469; Cameron, supra, note 5; and Bredt \& Dodek, supra, note 5.

86 Professor Cameron has recently written about the Supreme Court's infidelity to the structural logic of the Charter. See Cameron, supra, note 5.

87 Cameron, supra, note 5 , at 35. 
claimant under section 15 will be required to demonstrate to the court that the impugned legislation has a discriminatory effect on an enumerated or analogous group. This will likely require detailed empirical evidence that is able to demonstrate the legislation's impact on a particular class of individuals. This in itself is a difficult task for a prospective litigant. However, the challenge is compounded when the litigant is required to adduce evidence under the Law methodology to prove a violation of human dignity, including evidence of historic disadvantage, stereotyping, correspondence between the basis for the claim and the actual situation of the claimant; the ameliorative purpose or effects of the impugned legislation upon a more disadvantaged group; and the nature and scope of the interest affected by the impugned legislation. Moreover, because the list of contextual factors is open-ended, the rights claimant, while having the opportunity to adduce additional evidence, may be faced with other "contextual factors" for which she has not developed evidence. The claimant may not even know the case he or she is to meet in order to prove his or her claim.

\section{(c) Transparency, Clarity, and the Rule of Law}

The modified Andrews approach attempts to inject greater transparency in the analysis of equality claims by clearly identifying a more limited number of objective factors for the court to consider and by discarding hopelessly subjective concepts such as "human dignity." In transferring all considerations of reasonableness from the breach to the justification stage, this approach also heightens government accountability. The modified Andrews approach proposed in this paper thus establishes a framework that is easier for equality claimants and their lawyers to understand and for courts to apply. Transparency, clarity, and greater predictability are the essence of the rule of law. ${ }^{88}$

\section{(d) Response to Critics}

The enumerated and analogous grounds approach upon which our modified Andrews approach is based has been attacked on the grounds that it is

88 The rule of law is "a highly textured expression, importing many things ... but conveying, for example, a sense of orderliness, of subjection to known legal rules and of executive accountability to legal authority." See Patriation Reference, supra, note 56, at 805-06. In the Quebec Secession Reference, supra, note 56, the Court explained that "[a]t its most basic level the rule of law vouchsafes to the citizens and residents of the country a stable, predictable and ordered society in which to conduct their affairs." Id., at para. 70 . 
formalistic and inconsistent with substantive equality. ${ }^{89}$ We disagree because we do not believe that a consensus exists as to the meaning of substantive equality. This is demonstrated by the cases following Law in which the Supreme Court has been sharply divided on this issue. Support for substantive equality simply does not assist in establishing a workable framework for adjudication of section 15 claims.

As to the charge of formalism, we acknowledge that in attempting to articulate a more objective test, our approach is both under-inclusive and overinclusive. However, for all the reasons set out above, we believe that this is preferable to the unbridled subjectivity of Law and of the abstract and uncertain principles propounded by the proponents of substantive equality.

A modified Andrews approach is under-inclusive in the sense that it does not catch all "discrimination," but only that on enumerated or analogous grounds. Essentially, this gives the legislature a license to discriminate on all other bases. We accept this and acknowledge that discrimination in the neutral sense of the term is the business of legislating. If, as some have argued, ${ }^{90}$ all legislation that discriminates in the sense of drawing a distinction between classes of people should be held to violate section 15(1) and require justification under section 1, then every single piece of legislation would be susceptible to a Charter challenge. ${ }^{91}$ This would import an aspect of American equal protection analysis that does not accord with our constitutional history. ${ }^{92}$

89 See Greschner, supra, note 51, at 308 and Douglas Kropp, “' Categorical' Failure: Canada's Equality Jurisprudence - Changing Notions of Identity and the Legal Subject” (1997) 21 Queen's L.J. 201.

90 See Hogg, Constitutional Law of Canada, 2nd ed., supra, note 7, at 797-801; and Cameron, supra, note 5 , at 40 .

91 Professor Hogg noted that virtually any benefit programs were susceptible to a charge of underinclusiveness. See Peter W. Hogg, Constitutional Law of Canada, 3rd ed. (Toronto: Carswell, 1992), at 911-12.

92 Under such a framework, one would have to begin to articulate a purpose for s. 15 that focused far more on individuals and their interaction with government than on historicallydisadvantaged or discriminated-against groups. One would have to articulate a purpose that argues that government must be absolutely neutral in its dealings with all citizens. While such a libertarian argument may be philosophically defensible, it does not accord with the history of the Canadian state and the role of government, let alone with the "Trudeau vision" of a "Just Society" fuelled by undisciplined government spending and intervention in all aspects of society. See generally Andrew Coyne, "Social Spending, taxes, and the Debt: Trudeau's Just Society" in Andrew Cohen \& J.L. Granatstein, eds., Trudeau's Shadow (Toronto: Random House of Canada, 1998), at 223; Thomas S. Axworthy \& Pierre Eliott Trudeau, Towards a Just Society: The Trudeau Years (Toronto: Viking, 1990); and Stephen Clarkson \& Christina McCall, Trudeau and Our Times: Volume 2: The Heroic Delusion (Toronto: McClelland \& Stewart, 1994). The idea of absolute state neutrality would be anathema to many of the persons who were the driving force behind the constitutionalization of a bill of rights for Canada. 
The modified Andrews approach is also over-inclusive in the sense that some distinctions which are considered acceptable in society will meet both components of the section 15(1) test and be held to be prima facie discriminatory. We see this as an issue for section 1, not for section 15(1). Requiring the government to justify all distinctions based on enumerated and analogous grounds is desirable. It forces government to articulate reasons for long-held policies which may or may not change over time.

We do not believe that the Oakes test should be used to straightjacket the interpretation of section 15. Fear that the rigidity of the Oakes test will result in much legislation being struck down or in the Oakes test being watered-down is overstated. The practical reality is that Oakes is not monolithic - for example, the Supreme Court applies a much different Oakes test when it considers a commercial expression claim under section $2(b)$ than it does when considering a criminal defendant's rights under section 11. Explicit recognition or reconsideration of different applications of section 1 by the Court would also be welcome.

Our hope is to inject greater transparency into the adjudication of equality claims under section 15 by forcing courts to make explicit many assumptions that have heretofore been implicit and allowed to be buried under layer upon layer of "context."

\section{CONCLUSION}

In this difficult and controversial area of the law, we make no pretensions of having found the Rosetta Stone to unlocking equality. However, we do believe that a modified Andrews approach based on the principles and the framework set out in Andrews is a preferable approach to what has developed since. Focusing on concepts such as substantive equality and human dignity at the section 15(1) stage is a hopelessly abstract and subjective enterprise which is well-suited to legislative policy discussions and philosophy classes, but not to the process of adjudication. Sometimes additional attempts to tweak the picture makes the whole screen more fuzzy. As Peter Hogg noted in commenting on post-Andrews jurisprudence, "[t]here is nothing wrong with this picture and I am at a loss to discover why the judges of the Supreme Court of Canada, having painted it so successfully in Andrews, have been struggling so hard to blur it ever since." 93

93 Hogg, Constitutional Law of Canada, loose-leaf ed., supra, note 74, at para. 52.7(b). 


\section{Cases}

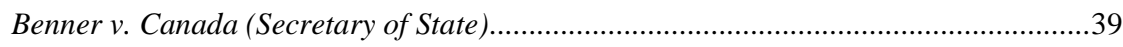

Catholic Children's Aid Society of Metropolitan Toronto v. S. (T.) ..................................51

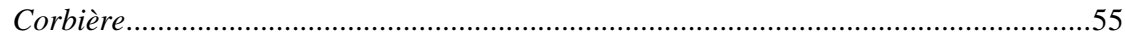

Corbière v. Canada (Minister of Indian and Northern Affairs) ......................................43

Egan v. Canada .................................................................................. 38, 39, 55

Gosselin v. Quebec ................................................................. 44, 45, 47, 50, 53, 58

Granovsky v. Canada (Minister of Employment and Immigration) ...................43, 48, 53

Lavoie v. Canada ...............................................................................................44, 50

Law …............................................... 33, 34, 40, 43, 44, 45, 46, 47, 53, 58, 61, 62

Law Society of British Columbia v. Andrews33, 34, 35, 36, 37, 38, 40, 48, 54, 55, 56, 59, $60,61,62,63$

Law v. Canada (Minister of Employment and Immigration) ........................................40

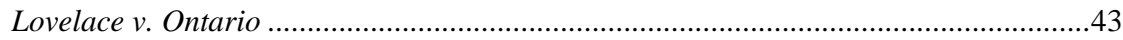

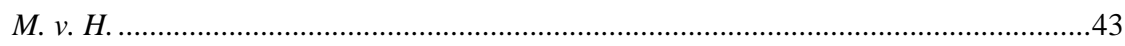

McKinney v. University of Guelph .................................................37, 38, 53, 58

Miron v. Trudel ........................................................................................38, 39, 40

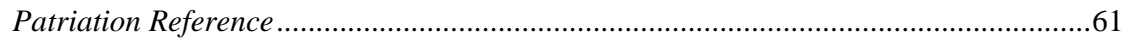

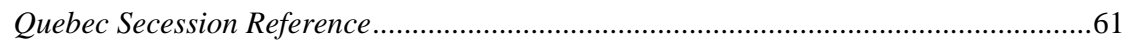

R. v. Oakes ….......................................................................... 46, 51, 58, 60, 63

Reference re Resolution to amend the Constitution ......................................................46

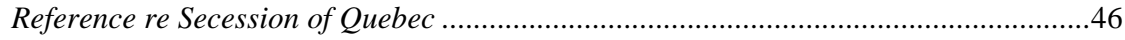

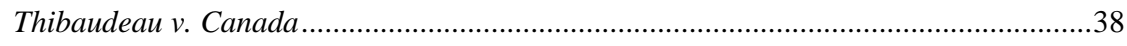

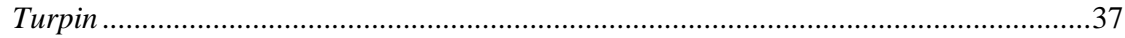

